antibodies previously present in the 10 cotwins in the long term group had disappeared in all but two (fig 3); (c) impairment of glucose tolerance was seen in cotwins in the short term group but not in those in the long term group; and $(d)$ a prospective study of 10 other cotwins of short term diabetics who had been discordant for more than 10 years showed an improvement in glucose tolerance over that time (Heaton et al, paper presented to the British Diabetic Association, Belfast, 1985).

We do not know what determines whether the damage to the islets will lead to complete destruction of the insulin secreting cells or to their recovery. If the destruction is an immune mediated process then it may be a question of the intensity of that process; it can hardly depend on genetic predisposition alone, as our results come from identical twin pairs.

If we could understand what limits the immune mediated damage in those twins in whom it had remitted we might learn how to arrest the process before it leads to diabetes.
We are grateful to the Medical Research Council, Wellcome Trust, British Diabetic Association, Novo, and Nordisk for funding this project. We thank Miss Anna Saunders, Mrs A Corcoran, and Mrs J John for technical work.

\section{References}

1 Cahill GF, McDevitt HO. Insulin-dependent diabetes mellitus: the initial lesion. $N$ Engl f Med 1981;304:1454-65

2 Bottazzo GF, Dean BM, Gorsuch AN, Cudworth AG, Doniach D. Complement-fixing islet-cel antibodies in type 1 diabetes: possible monitors of active beta-cell damage. Lancet $1980 ;$; $668-72$.

3 Alviggi L, Johnston C, Hoskins PJ, et al. Pathogenesis of insulin-dependent diabetes: a role for activated T-lymphocytes. Lancet 1984;ii:4-6.

4 Cudworth AG, Wolf $\mathrm{E}$. The genetic susceptibility to type 1 (insulin-dependent) diabetes mellitus. In: Alberti KGMM, Johnston D, eds. Clinics in endocrinology and metabolism. Vol 11. No 2 . Philadelphia: W B Saunders, 1982:389-408

5 Barnett AH, Eff C, Leslie RDG, Pyke DA. Diabetes in identical twins. Diabetologia 1981;20:87-93. 6 Lampson LA, Levy R. Two populations of Ia-like molecules on a human B cell line. 7 Immuno 1980;125:293-9.

(Accepled 6 fanuary 1986)

\title{
Effect of pregnancy on moderate renal failure in reflux nephropathy
}

\author{
GAVIN J BECKER, BENNO U IHLE, KENNETH F FAIRLEY, MARCUS BASTOS, \\ PRISCILLA KINCAID-SMITH
}

\begin{abstract}
During a 10 year study of women with reflux nephropathy 20 women had plasma creatinine concentrations in the range $0 \cdot 2-0 \cdot 4 \mathrm{mmol} / 1(2 \cdot 3-4 \cdot 5 \mathrm{mg} / 100 \mathrm{ml})$. Six experienced pregnancies exceeding 12 weeks' gestation. Pregnancy was associated with rapid deterioration in function in all six, resulting in end stage renal failure in four women within two years after delivery despite adequate control of blood pressure. Of the 14 women who did not have a prolonged pregnancy, four had periods of uncontrolled hypertension, all of which were related to non-compliance or loss from follow up, or both. Uncontrolled hypertension was also associated with accelerated renal failure, and all four women progressed quickly to end stage renal failure. The remaining 10 women were observed for from five to 10 years; in all 10 renal function deteriorated slowly, and none reached end stage renal failure within seven years.

It is concluded that pregnancy in patients with reflux nephropathy and moderately severe renal failure has a deleterious effect on renal function.
\end{abstract}

\section{Introduction}

The effect of pregnancy on renal disease is controversial. Some reports suggest that it is deleterious, especially if renal function is already impaired. ${ }^{1-5}$ Others have argued that the rapid decline in renal function seen in some patients reflects the clinical course of the

\footnotetext{
Department of Nephrology, Royal Melbourne Hospital, Parkville 3050 Victoria, Australia

GAVIN J BECKER, MD, FRACP, physician

BENNO U IHLE, FRACP, FACP, physician

KENNETH F FAIRLEY, MD, FRACP, physician

MARCUS BASTOS, MD, research fellow

PRISCILLA KINCAID-SMITH, MD, FRACP, director of nephrology and professor of medicine, University of Melbourne

Correspondence to: Dr Becker.
}

underlying disease..$^{6-11}$ We have reported a high incidence of complications in gravidas with reflux nephropathy. ${ }^{12}$ Since 1973 we have prospectively studied patients presenting with reflux nephropathy to determine the features associated with a poor prognosis. We now present our findings.

\section{Patients and methods}

During a prospective 10 year study of patients with reflux nephropathy six women with plasma creatinine concentrations of $0 \cdot 2-0 \cdot 4 \mathrm{mmol} / \mathrm{l}(2 \cdot 3-4 \cdot 5 \mathrm{mg} /$ $100 \mathrm{ml}$ ) experienced pregnancies exceeding 12 weeks' gestation. The course of renal disease during and after the pregnancy in these six patients was compared with that in 14 women with the same degree of renal impairment who did not experience prolonged pregnancy.

Reflux nephropathy was considered to be present if the patient had the typical radiological features of clubbed polar renal calices with overlying cortical scars. ${ }^{13}$ In all but one vesicoureteral reflux had been shown at some time on micturating cystography. In 15 from whom renal biopsy tissue was available, including the one in whom reflux had not been documented, histological findings were typical. ${ }^{14}$ Plasma creatinine and urea concentrations were determined by autoanalyser (Technikon SMAC).

\section{Results}

Twenty women with reflux nephropathy had plasma creatinine concentrations in the range $0 \cdot 2-0 \cdot 4 \mathrm{mmol} / 1(2 \cdot 3-4 \cdot 5 \mathrm{mg} / 100 \mathrm{ml})$ in the 10 years 1973-83.

\section{PATIENTS WITH PROLONGED PREGNANCIES}

Six patients (mean age 26.0 (range 21-39) years) experienced pregnancies exceeding 12 weeks (table). All had plasma creatinine concentrations exceeding $0.2 \mathrm{mmol} / 1(2.3 \mathrm{mg} / 100 \mathrm{ml})$ before 20 weeks' gestation. In one case the fetus died in utero at 22 weeks, and one woman w as delivered at 30 weeks of a baby that died of hyaline membrane disease. In the remaining four cases the babies were delivered at 30-38 weeks' gestation; all four babies survived. Four patients were treated during pregnancy with plasma exchange, in two cases after intravenous heparin treatment.

Renal biopsy was performed during pregnancy in two cases and within one month after delivery in one. All specimens showed considerable focal 
and segmental glomerular hyalinosis and sclerosis and pronounced hyperplasia of vascular intima. One of the specimens obtained during pregnancy also showed fibrinoid intraglomerular lesions. The changes of pronounced vascular intimal hyperplasia and fibrinoid intravascular lesions were not seen in 11 biopsy specimens from patients with controlled blood pressure who were not pregnant at the time.

The table and figure 1 show the course of renat function in these six patients. Pregnancy was associated with deterioration of renal function in all cases, and further rapid deterioration occurred post partum, even in two patients who had had fairly stable function for years previously. This deterioration occurred despite close attention to control of hypertension (diastolic blood pressure did not exceed $100 \mathrm{~mm} \mathrm{Hg}$ ) and salt and water balance and absence of urinary infection. Four of the six patients were in end stage renal failure within two years after delivery.

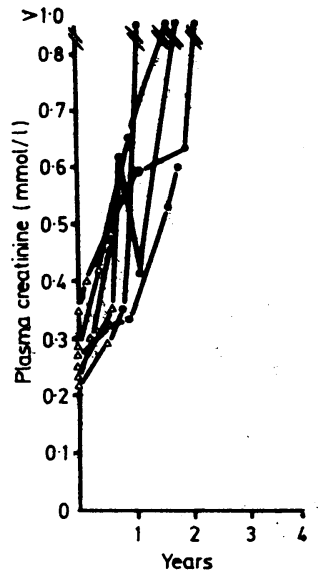

FIG 1 - Course from early pregnancy in six patients with plasma creatinine concentration $0.2-0.4 \mathrm{mmol} / \mathrm{l}$ in first trimester of pregnancy lasting 20 weeks or more. $\Delta-\triangle=$ Values during pregnancy. $=$ Values post partum.

Conversion: SI to traditional units-Creatinine: $1 \mathrm{mmol} / \mathrm{l} \approx 11.3 \mathrm{mg} / 100 \mathrm{ml}$

\section{PATIENTS WITH ACCELERATED HYPERTENSION}

Four patients (mean age 23.0 (range 17-23 years) had periods of accelerated hypertension associated with rapid decline in renal function (fig 2). Three had been lost to follow up for from six months to three and a half years before returning; two were in or near end stage renal failure. The third had been observed for 17 months with a stable plasma creatinine concentration of $0.13 \mathrm{mmol} / \mathrm{l}(1.5 \mathrm{mg} / 100 \mathrm{ml})$ before she was lost to follow up for three and a half years. Two years before representing she completed a pregnancy complicated by hypertension, and she was referred back to us with a plasma creatinine concentration of $0.29 \mathrm{mmol} / \mathrm{l}(3.3 \mathrm{mg} / 100 \mathrm{ml})$, a diastolic blood pressure of $130 \mathrm{~mm} \mathrm{Hg}$, and retinal haemorrhages. She rapidly progressed to end stage renal failure despite control of hypertension. The fourth patient was non-compliant and usually had a diastolic blood pressure exceeding $120 \mathrm{~mm} \mathrm{Hg}$.

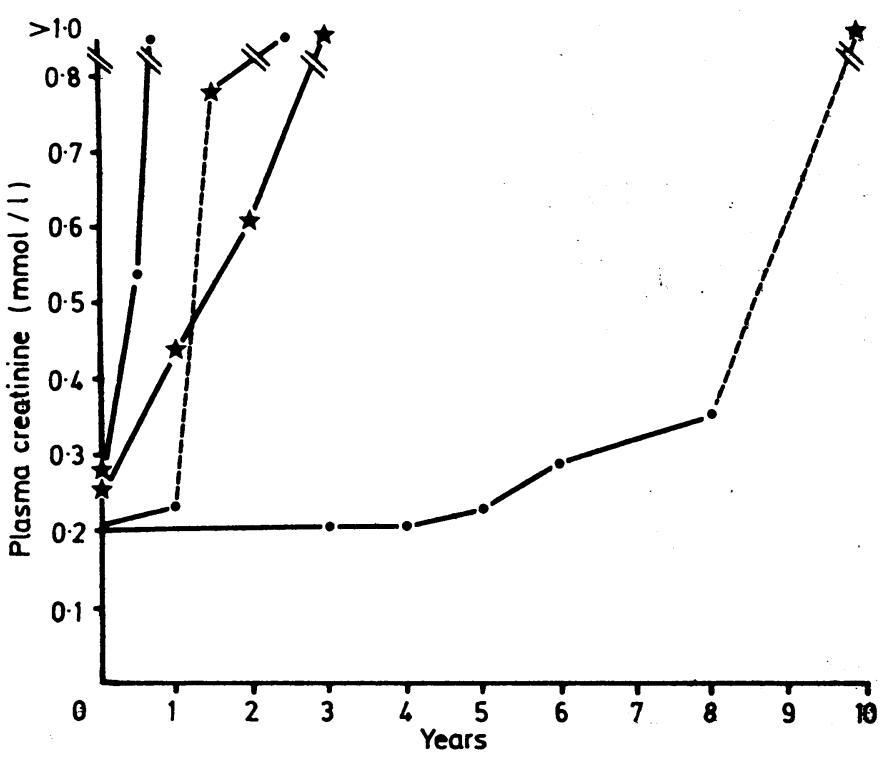

FIG 2-Course in patients with plasma creatinine concentration $0 \cdot 2-0.4 \mathrm{mmol} / \mathrm{l}$ who experienced uncontrolled blood pressure $(>120 \mathrm{~mm} \mathrm{Hg}$ diastolic). (Graph bégins at first recorded plasma creatinine concentration $\geqslant 0.2 \mathrm{mmol} / 1$. $=$ Controlled blood pressure. $\cdots=$ Lost to follow up $\star=$ Diastolic blood pressure $>120 \mathrm{~mm} \mathrm{Hg}$

Conversion: SI to traditional units_-Creatinine: $1 \mathrm{mmol} / \mathrm{l} \approx 11.3 \mathrm{mg} / 100 \mathrm{ml}$.

\section{PATIENTS WITH CONTROLLED HYPERTENSION AND NO PREGNANCIES}

Ten patients (mean age $29 \cdot 4$ (range 16-53) years) in whom neither pregnancy nor accelerated hypertension occurred showed slow deterioration of renal function (fig 3). All had hypertension controlled with antihypertensive drugs. In no case was the deterioration as rapid as that seen in the pregnant patients or those with accelerated hypertension.

\section{Discussion}

In this study of women with reflux nephropathy and moderate renal failure renal function slowly deteriorated in 10 patients who did not experience prolonged pregnancy ( $>12$ weeks) or uncontrolled hypertension. None of these patients reached end stage renal failure in less than seven years from the first time their plasma creatinine concentration reached $0.2 \mathrm{mmol} / \mathrm{l}$ or more $(\geqslant 2.3 \mathrm{mg} /$ $100 \mathrm{ml}$ ). Renal function deteriorated rapidly in all six patients who experienced pregnancies exceeding 12 weeks' gestation and in four patients who had periods of accelerated hypertension. In the pregnant patients this deterioration occurred during pregnancy and post partum despite good control of blood pressure. Four of the six were in end stage renal failure within two years after delivery.

Renal function and outcome of pregnancy in pregnant patients

\begin{tabular}{|c|c|c|c|c|c|c|c|c|c|c|c|}
\hline \multirow[b]{2}{*}{$\begin{array}{l}\text { Case } \\
\text { No }\end{array}$} & \multirow[b]{2}{*}{$\begin{array}{c}\text { Age at } \\
\text { conception } \\
\text { (years) }\end{array}$} & \multicolumn{3}{|c|}{ Initial follow up } & \multicolumn{3}{|c|}{ Follow up during pregnancy } & \multicolumn{3}{|c|}{ Subsequent follow up } & \multirow[b]{2}{*}{ Fetal outcome } \\
\hline & & $\begin{array}{c}\text { Time } \\
\text { before } \\
\text { pregnancy }\end{array}$ & $\begin{array}{l}\text { Plasma } \\
\text { creatinine } \\
(\mathrm{mmol} / \mathrm{l})\end{array}$ & $\begin{array}{c}\text { Urine } \\
\text { protein } \\
(\mathrm{g} / 24 \mathrm{~h})\end{array}$ & $\begin{array}{c}\text { Gestation } \\
\text { (weeks) }\end{array}$ & $\begin{array}{l}\text { Plasma } \\
\text { creatinine } \\
(\mathrm{mmol} / \mathrm{l})\end{array}$ & $\begin{array}{c}\text { Urine } \\
\text { protein } \\
(\mathrm{g} / 24 \mathrm{~h})\end{array}$ & $\begin{array}{c}\text { Time after } \\
\text { delivery } \\
\text { (months) }\end{array}$ & $\begin{array}{c}\text { Plasma } \\
\text { creatinine } \\
(\text { mmoll })\end{array}$ & $\begin{array}{c}\text { Urine } \\
\text { protein } \\
(\mathrm{g} / 24 \mathrm{~h})\end{array}$ & \\
\hline 1 & 39 & & & & $\begin{array}{l}16 \\
30\end{array}$ & $\begin{array}{l}0.24 \\
0.29\end{array}$ & $\begin{array}{l}1 \cdot 4 \\
1 \cdot 2\end{array}$ & 8 & $1 \cdot 21$ & $3 \cdot 2$ & $850 \mathrm{~g}$, died at 6 days \\
\hline 2 & 21 & $\left\{\begin{array}{l}8 \text { years } \\
3 \text { years }\end{array}\right.$ & $\begin{array}{l}0 \cdot 10 \\
0 \cdot 20\end{array}$ & & $\begin{array}{r}4 \\
30\end{array}$ & $\begin{array}{l}0.25 \\
0.29\end{array}$ & $\begin{array}{l}2 \cdot 1 \\
2 \cdot 0\end{array}$ & 12 & 0.93 & $2 \cdot 9$ & $1090 \mathrm{~g}$, survived \\
\hline 3 & 21 & & & & $\begin{array}{l}20 \\
38\end{array}$ & $\begin{array}{l}0 \cdot 25 \\
0 \cdot 42\end{array}$ & $3 \cdot 0$ & 12 & $1 \cdot 8$ & $2 \cdot 5$ & Survived \\
\hline 4 & 24 & & & & $\begin{array}{l}20 \\
22\end{array}$ & $\begin{array}{l}0.35 \\
0.50\end{array}$ & $\begin{array}{l}1.4 \\
3.9\end{array}$ & 23 & $1 \cdot 0$ & $2 \cdot 7$ & Death at 22 weeks \\
\hline 5 & 29 & $\left\{\begin{array}{c}10 \text { years } \\
6 \text { months }\end{array}\right.$ & $\begin{array}{l}0.14 \\
0.27\end{array}$ & $\begin{array}{l}4 \cdot 0 \\
1 \cdot 2\end{array}$ & $\begin{array}{r}8 \\
30\end{array}$ & $\begin{array}{l}0.26 \\
0.31\end{array}$ & $\begin{array}{l}1 \cdot 2 \\
1 \cdot 3\end{array}$ & $\begin{array}{r}6 \\
12 \\
18\end{array}$ & $\begin{array}{l}0.60 \\
0.88 \\
0.84\end{array}$ & $\begin{array}{l}2 \cdot 0 \\
2 \cdot 2 \\
2 \cdot 1\end{array}$ & $1368 \mathrm{~g}$, survived \\
\hline 6 & 21 & & & & $\begin{array}{l}12 \\
30\end{array}$ & $\begin{array}{l}0.22 \\
0.34\end{array}$ & $\begin{array}{l}3 \cdot 1 \\
5 \cdot 2\end{array}$ & $\begin{array}{r}5 \\
12\end{array}$ & $\begin{array}{l}0.47 \\
0.52\end{array}$ & & $1498 \mathrm{~g}$, survived \\
\hline
\end{tabular}




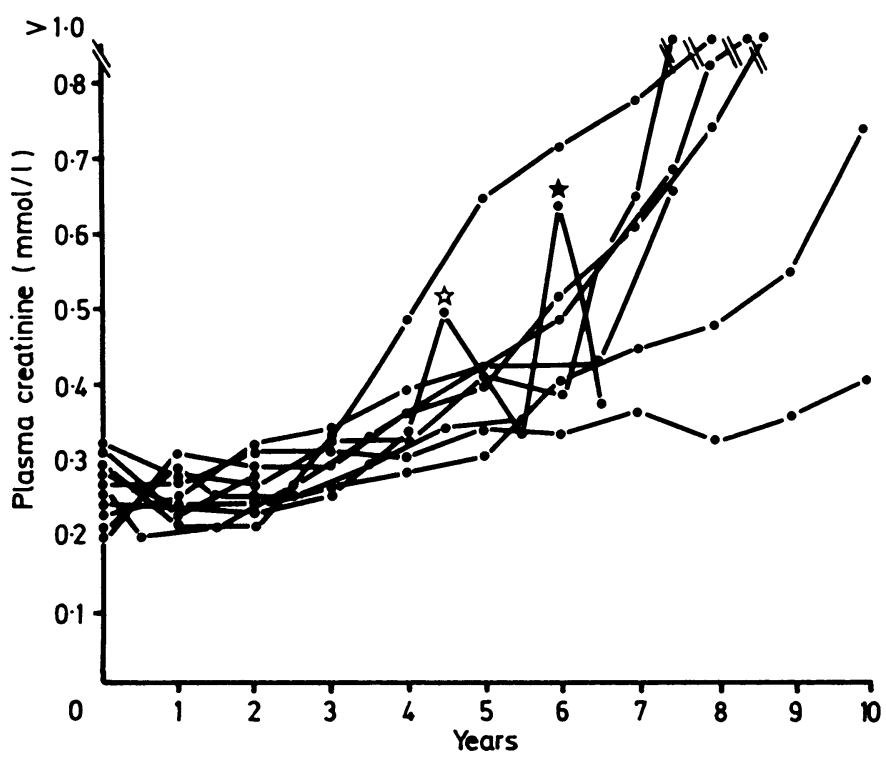

FIG 3 - Course in patients with plasma creatinine concentration $0 \cdot 2-0.4 \mathrm{mmol} /$ who did not experience prolonged pregnancy or uncontrolled blood pressure (Graph begins at first recorded plasma creatinine $\geqslant 0.2 \mathrm{mmol} / \mathrm{l}$.) 2$\}=$ Pregnancy to 12 weeks' gestation. $\downarrow=$ Uretic obstruction by calculus.

Conversion: SI to traditional units-Creatinine: $1 \mathrm{mmol} / 1 \approx 11.3 \mathrm{mg} / 100 \mathrm{ml}$.

This poor prognosis in pregnant patients with reflux nephropathy and a plasma creatinine concentration greater than $0.2 \mathrm{mmol} / \mathrm{l}$ is similar to that in isolated patients reported on previously, ${ }^{3}{ }^{15} 16$ all three of whom were in or near end stage renal failure within 18 months after delivery. The normally slow progress of the disease in the absence of hypertension or pregnancy is consistent with findings in other series. ${ }^{1718}$ The cause of this decline in renal function related to pregnancy is uncertain, although several contributing lesions might be responsible. Worsening of vesicoureteral reflux by pregnancy is unlikely to contribute. Two of our six patients had undergone successful reimplantation of their ureters before their pregnancies. The fairly high blood pressures experienced intermittently during pregnancy may have contributed, but the diastolic pressure did not exceed $100 \mathrm{~mm} \mathrm{Hg}$.

We previously suggested that acute fibrinoid vascular lesions, such as those that occur in postpartum renal failure, may play a part. ${ }^{19}$ Pregnancy accelerates focal and segmental glomerular hyalinosis and sclerosis in patients with glomerulonephritis. ${ }^{19} 20$ All three patients who underwent renal biopsy showed evidence of this complication of reflux nephropathy, which is usually accompanied by increased proteinuria, hypertension, and deterioration in renal function. ${ }^{14}$ One patient in this series showed acute intraglomerular fibrin thrombi during pregnancy, lesions that may well precede segmental hyalinosis. These lesions were not seen in patients who were not pregnant. Taylor $e t$ al suggested that pregnancy also has a similar deleterious effect in primary focal and segmental glomerular hyalinosis and sclerosis. ${ }^{21}$ Recently it has been suggested that focal and segmental glomerular hyalinosis and sclerosis results from glomerular overload, or hyperfiltration,,$^{22}$ a condition that could be worsened by the high glomerular filtration rate that persists throughout pregnancy. The mechanism by which hyperfiltration causes focal and segmental glomerular hyalinosis and sclerosis is unclear, although there is some evidence in animal models that drugs that inhibit intravascular coagulation can protect against focal and segmental glomerular hyalinosis and sclerosis. ${ }^{23}{ }^{24}$

A similar deleterious effect of pregnancy in other diseases causing renal failure seems likely. We reviewed reported cases of pregnancy in patients with glomerular lesions and found that deterioration of function was almost universal if plasma creatinine concentrations exceeded $0.2 \mathrm{mmol} / 1$ in the first trimester. ${ }^{25}$ Hou et al reported a series of 25 pregnancies in women with a plasma creatinine concentration $\geqslant 0.12 \mathrm{mmol} / 1(\geqslant 1.4 \mathrm{mg} / 100 \mathrm{ml})$ and found a dramatic decline in renal function in almost one third of these patients; three patients had a plasma creatinine concentration of $\geqslant 0.2 \mathrm{mmol} / \mathrm{l}$, and all suffered a decline in renal function. As in our series the deterioration continued after delivery, a phenomenon of great importance. The mechanisms are likely to be similar.

The suggestion that intravascular thrombosis might play a part in the pathogenesis of the deterioration in renal function related to pregnancy led us to use antithrombotic agents such as antiplatelet drugs, heparin ${ }^{26}$ and, more recently, plasma exchange ${ }^{27}{ }^{28}$ in the treatment of such patients. Four of the current series of patients were treated with heparin or plasma exchange, or both, and three delivered live babies. ${ }^{28}$ The aggressive treatment during pregnancy did not prevent rapid postpartum deterioration in renal function. In fact, by prolonging the pregnancy it may have worsened the maternal prognosis. In four patients plasma exchange was continued for between two weeks and three months post partum. Renal function partially stabilised during this time in three patients but deteriorated subsequently.

We believe that women with reflux nephropathy and impaired renal function (plasma creatinine concentration $>0.2 \mathrm{mmol} / \mathrm{l}$ ) should be warned that end stage renal failure is likely to occur as a result of pregnancy.

MB was supported by Conseluo Nacional de Desenvolimento e PesquitaCNP, Brazil.

\section{References}

1 Mackay EV. Pregnancy and renal disease. A ten year survey. Aust NZ $\mathcal{J}$ Obstet Gynaecol 1963;3:21-34.

2 Kincaid-Smith P, Fairley KF, Bullen M. Kidney disease and pregnancy. Med $\mathcal{J}$ Aust 1967;2: $1155-9$.

Bear RA. Pregnancy in patients with renal disease. A study of 44 cases. Obstet Gynecol 1976;48: $13-6$.

Klockars M, Saarikoski S, Ikonen E, Kuhlback B. Pregnancy in patients with renal disease. Acta Med Scand 1980;207:207-14.

5 Hou SH, Grossman DS, Madias NE. Pregnancy in women with renal disease and moderate renal insufficiency. Am $\mathcal{F}$ Med 1985; 78: 185-94.

6 Strauch BS, Hayslett JP, Kidney disease and pregnancy. Br Med 7 1974;iv:578-82

7 Leppert P, Tisher CC, Shu-Chung SC, Harlan WR. Antecedent renal disease and the outcome of pregnancy. Ann Intern Med 1979;90:747-51.

8 Weiser EB, O'Brien WF, Cegalo RC. Perinatal risk factors in gravidas with moderate rena impairment. South Med f 1980;73:1226-8.

9 Katz AI, Davison JM, Hayslett JP, Singson E, Lindheimer MD. Pregnancy in women with kidney disease. Kidney Int 1980;18:192-206.

10 Hirsch DJ, Hayslett JP. Management of renal disease during pregnancy. Kidney 1982;15:29-33. 1 Surian M, Imbasciatti E, Cosci P, et al. Glomerular disease and pregnancy. Nephron 1984;36: $101-5$

12 Kincaid-Smith P, Becker GJ. Reflux nephropathy in the adult. In: Hodson J, Kincaid-Smith P eds. Reflux nephropathy. New York: Masson Publishing USA Inc, 1970:21-7.

13 Medical Research Council Committee. Recommended terminology of urinary tract infection. $B$ Med f 1979;ii:717-9.

14 Kincaid-Smith $P$. Diffuse parenchymal disease in reflux nephropathy and the possibility of making a renal biopsy diagnosis. In: Hodson CJ, Heptinstall RH, Winberg J, eds. Reflux nephropathy update. Basle: Karger, 1984:111-5. (Contributions to Nephrology Vol 139.

15 Orme BM, Ueland K, Simpson DP, Scribner BH. The effect of hemodialysis on fetal survival and renal function in pregnancy. Trans Am Soc Artif Intern Organs 1968;14:402-4.

16 Johnson TR, Lorenz RP, Menon KMJ, Nolan GH. Successful outcome of a pregnancy requirin dialysis. F Reprod Med 1979;22:217-8.

17 Mihindukulasyriya JCL, Maskell R, Polak A. A study of 58 patients with renal scarring associated with urinary tract infection. $Q \mathcal{J}$ Med 1980;194:165-78.

18 Arze RS, Ramos JM, Owen JP, et al. The natural history of chronic pyelonephritis in the adult. Qf Med 1982;204:396-410.

19 Kincaid-Smith P. Pre-eclampsia toxaemia, hypertension and renal disease in pregnancy. In: Kincaid-Smith P, ed. The kidney. A clinicopathological study. Oxford: Blackwell Scientific, 1975:222-39.

20 Whitworth JA, Kincaid-Smith P, Fairley KF. The outcome of pregnancy in mesangial IgA nephropathy. In: Sammour MB, Symonds EM, Zuspan P, El Tomi N, eds. Pregnancy hypertension. Cairo: Ains Shams University Press, 1982:403-8.

21 Taylor J, Novak R, Christiansen R, Sorensen ET. Focal sclerosing glomerulopathy with adverse effects during pregnancy. Arch Intern Med 1978;138:1695-6.

22 Brenner BM, Meyer TW, Hostetter JM. Dietary protein intake and the progressive nature of kidney disease. The role of hemodynamically mediated glomerular injury in the pathogenesis of glomerular-sclerosis in ageing, renal ablation and intrinsic renal disease. $N$ Engl f Med 1982;307:652-9.

23 Purkerson ML, Hoffsten PE, Klahr S. Pathogenesis of the glomerulopathy associated with renal infarction in rats. Kidney Int 1976;9:407-17.

24 Olson JL. Role of heparin as a protective agent following reduction of renal mass. Kidney Int 1984;25:376-82.

25 Becker GJ, Fairley KF, Whitworth JA. Pregnancy exacerbates glomerular disease. Am $\mathcal{f}$ Kidney Dis 1985:6:266-72.

26 Fairley KF, Adey FD, Ross IC, Kincaid-Smith P. Heparin treatment in severe pre-eclampsia and glomerulonephritis in pregnancy. In: Lindheimer MD, Katz AI, Zuspan FP, eds. Hypertension and pregnancy, perspectives in nephrology. New York: John Wiley, 1976:103-12.

27 d'Apice AJF, Reti LL, Pepperell RJ, Fairley KF, Kincaid-Smith P. Treatment of severe preeclampsia by plasma exchange. Aust NZ J Obstet Gynaecol 1980;20:231-5.

28 Becker G, Ihle B, Fairley K, d'Apice AJF, Kincaid-Smith P. Plasma exchange in pregnancy complicated renal failure due to reflux nephropathy [Abstract]. Clin Exp Hypertens [B] 1984;3:329.

(Accepted 3 February 1986) . . . 